\title{
Dietary phosphatidylcholine impacts on growth performance and lipid metabolism in adult Genetically Improved Farmed Tilapia (GIFT) strain of Nile tilapia Oreochromis niloticus
}

\author{
Juan Tian†, Hua Wen†, Xing Lu, Wei Liu, Fan Wu, Chang-Geng Yang, Ming Jiang and Li-Juan Yu* \\ Key Lab of Freshwater Biodiversity Conservation Ministry of Agriculture, Ministry of Agriculture, Yangtze River Fisheries \\ Research Institute, Chinese Academy of Fishery Sciences, Wuban 430223, People's Republic of China
}

(Submitted 18 May 2017 - Final revision received 1 October 2017 - Accepted 5 October 2017 - First published online 11 December 2017)

\section{Abstract}

This study aimed to determine the effects of supplementing the diet of adult Nile tilapia Oreochromis niloticus with phosphatidylcholine (PC) on growth performance, body composition, fatty acid composition and gene expression. Genetically Improved Farmed Tilapia fish with an initial body weight of 83.1 (sD 2.9) g were divided into six groups. Each group was hand-fed a semi-purified diet containing 1.7 (control diet), $4 \cdot 0,6 \cdot 5,11 \cdot 5,21.3$ or $41.0 \mathrm{~g} \mathrm{PC} / \mathrm{kg}$ diet for $68 \mathrm{~d}$. Supplemental PC improved the feed efficiency rate, which was highest in the $11 \cdot 5 \mathrm{~g}$ PC/ $\mathrm{kg}$ diet. Weight gain and specific growth rate were unaffected. Dietary PC increased PC content in the liver and decreased crude fat content in the liver, viscera and body. SFA and MUFA increased and PUFA decreased in muscle with increasing dietary PC. Cytoplasmic phospholipase $A_{2}$ and secreted phospholipase $A_{2}$ mRNA expression were up-regulated in the brain and heart in PC-supplemented fish. PC reduced fatty acid synthase mRNA expression in the liver and visceral tissue but increased expression in muscle. Hormone-sensitive lipase and lipoprotein lipase expression increased in the liver with increasing dietary PC. Growth hormone mRNA expression was reduced in the brain and insulin-like growth factor-1 mRNA expression in liver reduced with PC above $6.5 \mathrm{~g} / \mathrm{kg}$. Our results demonstrate that dietary supplementation with PC improves feed efficiency and reduces liver fat in adult Nile tilapia, without increasing weight gain, representing a novel dietary approach to reduce feed requirements and improve the health of Nile tilapia.

\section{Key words: Phosphatidylcholine: Phospholipase $\mathbf{A}_{2}$ : Lipid metabolic enzymes: Growth: Tilapia}

The beneficial effects of dietary phospholipids (PL) on growth and survival have been demonstrated in the larval and juvenile stages of aquatic livestock species ${ }^{(1,2)}$. The beneficial effects of PL were not solely because of enhanced emulsification and digestion of lipids ${ }^{(3-5)}$, but also because of increased efficiency of dietary fatty acids and lipid transport from the gut to the rest of the body, potentially through enhanced lipoprotein synthesis ${ }^{(6-8)}$. Salmon and white sturgeon weighing more than $10 \mathrm{~g}$ were not reported to have a dietary requirement for PL, although this is potentially because of the short duration and limited assessment methods used in these preliminary studies $^{(9,10)}$. To our knowledge, there have been no further studies investigating PL requirements in adult or individual fish weighing more than $50 \mathrm{~g}$. Dietary PL has been shown to alleviate signs of liver disease in human and animal studies ${ }^{(11-13)}$. Meanwhile, the carbohydrate- and lipid-rich diets widely used in fish farming owing to shortages of protein resources commonly lead to the accumulation of ectopic fat, liver fat, mesenteric fat and also fat in the muscles of larger fish ${ }^{(14,15)}$.
Therefore, dietary supplementation with PL is potentially beneficial in the larger juvenile and adult fish that are increasingly affected by liver disease and metabolic disorders.

Previous research has commonly used crude mixed preparations of PL, particularly soyabean lecithin and other plant PL or egg-yolk lecithin. As these different sources are enriched in varying types of PL, it has been difficult to clarify which PL classes are responsible for the beneficial effects ${ }^{(2)}$. Phosphatidylcholine (PC), the most abundant class of PL in the diet, shows the greatest effect on fish larval performance ${ }^{(16)}$, with other studies reporting that supplementation with PC contributes to survival and reduces larval deformities ${ }^{(6-19)}$. The expression and regulation of key genes involved in lipid metabolism in response to dietary PC has not previously been studied in fish, particularly in adult fish.

Fish possesses a similar set of enzymes involved in lipid metabolism to mammals, including lipoprotein lipase (LPL), a key enzyme in lipid deposition and metabolism ${ }^{(20)}$, hormonesensitive lipase (HSL), an enzyme involved in lipolysis ${ }^{(21)}$, fatty

Abbreviations: $\mathrm{CPLA}_{2}$, cytosolic phospholipase $\mathrm{A}_{2}$; FAS, fatty acid synthase; GH, growth hormone; HSL, hormone-sensitive lipase; IGF-1, insulin-like growth factor-1; LPL, lipoprotein lipase; PC, phosphatidylcholine; PLA 2 , phospholipase $\mathrm{A}_{2}$; sPLA 2 , secretory phospholipase $\mathrm{A}_{2}$.

* Corresponding author: L.-J. Yu, fax +86 27 81780157, email yulijuan@whu.edu.cn

$\dagger$ These authors contributed equally to this work. 
acid synthase (FAS), involved in lipogenesis ${ }^{(22)}$, and phospholipase $\mathrm{A}_{2}\left(\mathrm{PLA}_{2}\right)$, which catalyses the hydrolysis of membrane glycero $\mathrm{PL}^{(23)}$. Previous research in Otsuka Long-Evans Tokushima fatty rats has shown that the effects of dietary PC were attributable to the suppression of FAS activity in the liver ${ }^{(24)}$. Injection of PC also increases HSL transcription in mouse fat tissue ${ }^{(25)}$, and has suggested that secreted $\mathrm{PLA}_{2}$ has an important role in hepatic uptake and metabolism of $\mathrm{PC}^{(26)}$.

Tilapia is becoming one of the most important and fastestgrowing fish species in aquaculture. The Genetically Improved Farmed Tilapia (GIFT) strain is a new nationally certificated strain selected over 14 years and nine generations from the base strain of Nile tilapia ${ }^{(27)}$. The GIFT strain is among the most successful of the introduced farmed tilapia in China owing to its strong adaptability, rapid growth, high fecundity and broad diet. On the basis of weight gain and feed efficiency, Kasper \& Brown $^{(5)}$ concluded that PC is a beneficial nutrient for juvenile tilapia with an initial body weight of $12.4 \mathrm{~g}$ and recommended that purified diets fed to juveniles include $15 \mathrm{~g}$ PC/ $\mathrm{kg}$ diet.

In the present study, we aimed to investigate the effects of varying levels of dietary $\mathrm{PC}$ on growth performance, tissue composition and the fatty acid profile in the tissues of adult GIFT strain Nile tilapia fish. In addition, we determined the effect of dietary PC on the expression of enzymes involved in lipid metabolism. We hypothesised that dietary PC has beneficial physiological effects in adult Nile tilapia, mediated through the altered expression of lipid enzymes.

\section{Methods}

\section{Diets}

Six semi-purified diets were prepared. Casein, gelatin and soyabean meal, which were the main protein sources, provided
$30.6 \%$ dietary protein (the protein requirement for maximum growth performance of large tilapia is approximately $30 \%)^{(28)}$. Soyabean oil and PC were used as lipid sources; they provided $7 \cdot 6 \%$ dietary lipid for large tilapia ${ }^{(29)}$. The diets were supplemented with different levels of dietary PC - 0, 2.5, 5.0, 10·0, 20·0 or $40.0 \mathrm{~g} / \mathrm{kg}$ diet - and the dietary lipid levels were adjusted by the soyabean oil levels. The analysed level of PC in the six diets was 1.7 (the control group), $4 \cdot 0,6 \cdot 5,11.5,21.3$ and $41.0 \mathrm{~g} / \mathrm{kg}$ diet. The diet preparation was conducted as previously described $^{(29)}$. The ingredients and proximate composition and fatty acid profiles are shown in Tables 1 and 2.

\section{Experimental procedure}

The feeding trial was performed in an indoor recirculating aquarium system at the Yangtze River Fisheries Research Institute (Wuhan, Hubei Province, China). GIFT strain fish were obtained from the Guangxi tilapia national breeding farm (Nanning, Guangxi Province, China), and were maintained in a concrete pool $(3 \times 3 \times 5 \mathrm{~m})$ at the experimental base. During the acclimatisation period, fish were fed the basal diet to adjust to the experimental diets and environmental conditions for 2 weeks.

During the initial phase, fish were fasted for $24 \mathrm{~h}$ and weighed after being anaesthetised with $80 \mathrm{mg} / \mathrm{l} \mathrm{MS-222.} \mathrm{Adult}$ male fish (initial weight: 83.12 (SD 2.84)g) were randomly assigned to eighteen tanks (500 litres) with twenty fish/tank. Three tanks of fish were randomly assigned to each diet. To reduce pellet waste, fish were gradually hand-fed until they appeared satiated by observing their feeding behaviour. The fish were fed three times a day: 08.30, 12.30 and 16.30 hours (natural photoperiod). The feeding trial lasted $68 \mathrm{~d}$. During this period, food consumption and any fish deaths were recorded daily. The water was maintained at $28-34^{\circ} \mathrm{C}$, pH of $7 \cdot 4-7 \cdot 6$, with

Table 1. Composition and proximate analysis of the experimental diets

\begin{tabular}{|c|c|c|c|c|c|c|}
\hline Ingredients & G0 & G0.25 & G0.5 & G1 & G2 & G4 \\
\hline Casein & 200 & 200 & 200 & 200 & 200 & 200 \\
\hline Gelatin & 50 & 50 & 50 & 50 & 50 & 50 \\
\hline Soyabean meal & 200 & 200 & 200 & 200 & 200 & 200 \\
\hline Soyabean oil & 75 & 72.5 & 70 & 65 & 55 & 35 \\
\hline Phosphatidylcholine & 0 & $2 \cdot 5$ & $5 \cdot 0$ & 10 & 20 & 40 \\
\hline Dextrin & 340 & 340 & 340 & 340 & 340 & 340 \\
\hline Cellulose & 71.5 & 71.5 & 71.5 & 71.5 & 71.5 & 71.5 \\
\hline Monocalcium phosphate & 10 & 10 & 10 & 10 & 10 & 10 \\
\hline Vitamin premix ${ }^{*}$ & 10 & 10 & 10 & 10 & 10 & 10 \\
\hline Mineral premix $\dagger$ & 40 & 40 & 40 & 40 & 40 & 40 \\
\hline Choline chloride & $2 \cdot 5$ & 2.5 & $2 \cdot 5$ & $2 \cdot 5$ & $2 \cdot 5$ & 2.5 \\
\hline Butylated hydroxytoluene & 1 & 1 & 1 & 1 & 1 & 1 \\
\hline Total & 1000 & 1000 & 1000 & 1000 & 1000 & 1000 \\
\hline \multicolumn{7}{|c|}{ Proximate composition (g/kg diet) } \\
\hline DM & 909.9 & 915.5 & $913 \cdot 6$ & 913.5 & 913.7 & 913.9 \\
\hline Crude protein & $307 \cdot 6$ & $305 \cdot 6$ & $306 \cdot 5$ & $306 \cdot 2$ & $306 \cdot 6$ & $305 \cdot 8$ \\
\hline Crude lipid & 74.6 & $75 \cdot 7$ & $75 \cdot 4$ & 78.7 & $75 \cdot 1$ & $76 \cdot 4$ \\
\hline Ash & $39 \cdot 8$ & 39.9 & 39.5 & $40 \cdot 1$ & $41 \cdot 3$ & $42 \cdot 6$ \\
\hline Phosphatidylcholine & $1 \cdot 7$ & 4.0 & $6 \cdot 5$ & 11.5 & $21 \cdot 3$ & $41 \cdot 0$ \\
\hline
\end{tabular}

* Vitamin premix contained (g premix): thiamine hydrochloride, $5 \mathrm{mg}$; riboflavin, $5 \mathrm{mg}$; calcium pantothenate, $10 \mathrm{mg}$; nicotic acid, $6.05 \mathrm{mg}$; L-ascorbyl-2monophosphate-Mg, $3.95 \mathrm{mg}$; pyridoxine hydrochloride, $4 \mathrm{mg}$; folic acid, $1.5 \mathrm{mg}$; inositol, $200 \mathrm{mg}$; menadione, $4 \mathrm{mg}$; $\alpha$-tocopheryl acetate, $50 \mathrm{mg}$; retinyl acetate, $60 \mathrm{mg}$; biotin, $0.6 \mathrm{mg}$. All ingredients were diluted with $a$-cellulose to $1 \mathrm{~g}$.

† Mineral premix contained (kg diet): calcium biphosphate, $13.58 \mathrm{~g}$; calcium lactate, $32.7 \mathrm{~g} ; \mathrm{FeSO}_{4} \cdot 6 \mathrm{H}_{2} \mathrm{O}, 2.97 \mathrm{~g}$; magnesium sulphate, $13.7 \mathrm{~g}$; potassium phosphate dibasic, $23.98 \mathrm{~g}$; sodium biphosphate, $8.72 \mathrm{~g}$; sodium chloride, $4.35 \mathrm{~g} ; \mathrm{AlCl}_{3} .6 \mathrm{H}_{2} \mathrm{O}, 0.015 \mathrm{~g} ; \mathrm{KI}, 0.015 \mathrm{~g} ; \mathrm{CuCl}_{2}, 0.01 \mathrm{~g} ; \mathrm{MnSO}_{4} \cdot \mathrm{H}_{2} \mathrm{O}, 0.08 \mathrm{~g}$; $\mathrm{CoCl}_{2} \cdot 6 \mathrm{H}_{2} \mathrm{O}, 0 \cdot 1 \mathrm{~g} ; \mathrm{ZnSO}_{4} \cdot 7 \mathrm{H}_{2} \mathrm{O}, 0.3 \mathrm{~g}$ 
Table 2. Fatty acid composition (\% of total fatty acids) of the experimental diets

\begin{tabular}{lrrrrrr}
\hline Fatty acids & G0 & G0.25 & G0.5 & G1 & G2 & G4 \\
\hline SFA & & & & & & \\
C14:0 & 0.74 & 0.76 & 0.76 & 0.78 & 0.73 & 0.78 \\
C16:0 & 15.96 & 15.53 & 16.21 & 15.93 & 16.23 & 19.92 \\
$\quad$ C18:0 & 2.78 & 2.32 & 2.14 & 2.60 & 2.74 & 3.26 \\
MUFA & & & & 24.63 & 25.37 & 22.45 \\
$\quad$ C18: & 24.78 & 26.05 & 49.61 & 50.49 & 49.23 & 48.25 \\
$\begin{array}{l}n-6 \text { Fatty acids } \\
\quad \text { C18:2 }\end{array}$ & 50.25 & 49.52 & 48.75 & 5.57 & 5.70 & 5.34 \\
$\begin{array}{l}n-3 \text { Fatty acids } \\
\text { C18:3 }\end{array}$ & 5.49 & 5.82 & 5.59 & & & \\
\hline
\end{tabular}

Table 3. Nucleotide sequences of primers and cycling conditions used for PCR amplification

\begin{tabular}{lllll}
\hline Genes & Forward primer $\left(5^{\prime}-3^{\prime}\right)$ & Reverse primer $\left(5^{\prime}-3^{\prime}\right)$ & $\mathrm{T}_{\mathrm{m}}\left({ }^{\circ} \mathrm{C}\right)$ & Amplicon size (bp) \\
\hline FAS & TGAAACTGAAGCCTTGTGTGCC & TCCCTGTGAGCGGAGGTGATTA & 62 & 141 \\
LPL & TGCTAATGTGATTGTGGTGGAC & GCTGATTTTGTGGTTGGTAAGG & 59 & 217 \\
$H S L$ & GCCCTATCTAAAGAGTTGGTCC & CGATGTCGTCACACATAAGTTG & 62 & 214 \\
GH & ACAGCCAGCGTTTGTTTCCAT & GGAAACTCCCAGGACTCAACCA & 62 & 250 \\
$I G F-1$ & TGCGATGTGCTGTATCTCCTG & GCCATAGCCTGTTGGTTTATTG & 60 & 178 \\
SLPA 2 & TACAAGCCAGTGCCTCGTCC & AGGTGTCATAGCAGCGGTCA & 61 & 139 \\
CLPA 2 & ACCGTGAAGGTCTGAAGGAT & CTCAGGGTCGTCAAAAATGTC & 59 & 182 \\
$\beta-$ Actin & TGGTGGGTATGGGTCAGAAAG & CTGTTGGCTTTGGGGTTCA & $59-62$ & 216 \\
\hline
\end{tabular}

$\mathrm{T}_{\mathrm{m}}$, melting temperature; $F A S$, fatty acid synthase; $L P L$, lipoprotein lipase; $H S L$, hormone-sensitive lipase; GH, growth hormone; IGF-1, insulin-like growth factor-1; $S P L A_{2}$, secretory phospholipase $\mathrm{A}_{2} ; C P L A_{2}$, cytosolic phospholipase $\mathrm{A}_{2}$.

a dissolved $\mathrm{O}_{2}$ concentration $>6 \mathrm{mg} / \mathrm{l}$. During the feeding trial, fish were weighed and counted every 2 weeks after $24 \mathrm{~h}$ of fasting for analysis of growth and feeding. All experiments were conducted using a protocol approved by the Yangtze River Fisheries Research Institute, Chinese Academy of Fishery Sciences.

\section{Sample collection}

At the end of the experiment, fish were weighed and counted following a 24-h fast. Eight fish were removed from each tank using a dipnet and sedated with $80 \mathrm{mg} / \mathrm{l}$ MS-222 and were designated as the sample fish. The body weight of each sample fish was similar to the average fish weight of each tank. Three sample fish from each tank were killed and the bodies, viscera and liver were collected and weighed to determine the viscerosomatic index (VSI) and the hepatosomatic index (HSI). The liver, viscera and dorsal muscle tissues were stored at $-80^{\circ} \mathrm{C}$ until analysis of tissue composition and fatty acid analysis. A further two sample fish from each tank were killed for wholebody composition analyses. The whole body was first cut into small pieces with a knife, and then minced with a meat grinder; the minced meat was mixed thoroughly, and samples of approximately $100 \mathrm{~g}$ were taken from each fish and frozen at $-80^{\circ} \mathrm{C}$. The remaining three sample fish per tank were sedated with $80 \mathrm{mg} / \mathrm{l}$ MS-222, disinfected with $75 \%$ alcohol and killed. Approximately $0.2 \mathrm{~g}$ of brain, heart, liver, muscle and visceral tissue was placed in 2-ml microcentrifuge tubes, frozen in liquid $\mathrm{N}_{2}$ and stored at $-80^{\circ} \mathrm{C}$ until mRNA expression analyses.

\section{Biochemical analyses}

Crude protein, crude fat and ash contents were measured using the Micro-Kjeldahl, Soxhlet and ignition methods, respectively. Moisture content was determined using the freeze-drying method, in which samples were freeze-dried for $48 \mathrm{~h}$ in a vacuum freeze dryer (Christ Beta 2-4 LD plus LT; Marin Christ Corporation). Fatty acid content of diets and tissues was determined as previously described by Liu et al. ${ }^{(30)}$. Fatty acid methyl esters were separated, and quantified by GC-2010 gas chromatograph (SHIMADZU) with a fused silica capillary column (SP-2560; Supelco; $100 \mathrm{~m} \times 0.32 \mathrm{~mm}$ i.d., film thickness $0.20 \mu \mathrm{m})$ and a flame ionisation detector (FID). The thermal gradient programme was initially $100^{\circ} \mathrm{C}$ for $3 \mathrm{~min}$, followed by increments of $5^{\circ} \mathrm{C} / \mathrm{min}$ and finally $250^{\circ} \mathrm{C}$ for $10 \mathrm{~min}$. The injector and FID temperatures were $250^{\circ} \mathrm{C}$. PC contents in samples of the diets, muscle and liver were determined at the China National Analytical Center. The quantitative determination of PC in samples was conducted using the HPLC - Refractive Index (RI) method. A Waters Spherisorb S5W column $(4.6 \times 250 \mathrm{~mm}$ packed with $5-\mu \mathrm{m}$ silica $)$ and an isocratic mobile phase consisting of $n$-hexane-2propanol-water (1:4:1, by vol.) were used. The HPLC conditions were as follows: flow rate $0.8 \mathrm{ml} / \mathrm{min}$, injection aliquot $10 \mu \mathrm{l}$, column temperature $35^{\circ} \mathrm{C}$ and temperature of the RI detector (differential refractive index detector) $35^{\circ} \mathrm{C}$. The content of PC in samples was determined by the external standard method, using soyabean PC as the external standard.

The sequences of the primer pairs used for real-time PCR (RT-PCR) analysis of gene expression of secretory phospholipase $\mathrm{A}_{2}\left(\mathrm{sPLA}_{2}\right)$, cytosolic phospholipase $\mathrm{A}_{2}\left(\mathrm{CPLA}_{2}\right)$, FAS, LPL, HSL, growth hormone (GH), insulin-like growth factor-1 (IGF-1) and $\beta$-actin are shown in Table 3. $\beta$-actin was selected as the housekeeping gene for the normalisation of gene expression. RT-PCR reactions were conducted as previously described $^{(29)}$. 


\section{Statistical analyses}

The data were analysed using one-way ANOVA and Duncan's multiple-range tests using SPSS 17.0 for Windows (SPSS). Data are expressed as means and standard deviations in tables and figures. Differences were considered significant at $P<0.05$.

\section{Results}

\section{Growth performance and physiological parameters}

The effects on growth performance and physiological parameters of feeding adult Nile tilapia diets containing increasing amounts of PC are shown in Table 4 . Fish fed diets containing 4.0 to $21.3 \mathrm{~g} / \mathrm{kg}$ of PC showed a higher feed efficiency rate $(P<0.05)$ than those eating the control diet. The feeding rate was not significantly different among diet groups, ranging from 1.75 to $1.81 \%$. The weight gain and specific growth rate were lower in the G4 group than in the G0.5 group $(P<0.05)$, but no other differences were found in weight gain and specific growth rate between fish fed diets with added PC or the control diet. Fish in group G1 showed the highest VSI and HSI. No fish died during the feeding trial.

\section{Whole body and tissue composition}

Table 5 shows the effects of varying levels of dietary PC on whole body and tissue composition. As the amount of dietary PC increased, whole body crude fat content decreased from 10.79 to $9.77 \%(P<0.05)$, liver crude fat content decreased from 10.53 to $8.34 \%(P<0.05)$ and visceral crude fat content decreased from 21.95 to $19 \cdot 26 \%(P<0 \cdot 05)$. The crude fat content in muscle increased from 1.68 to $2.34 \%(P<0.05)$ as dietary PC levels increased from 1.7 to $11.5 \mathrm{~g} / \mathrm{kg}$ and then subsequently

Table 4. Growth performance and physiological parameters for Nile tilapia fed diets containing different phosphatidylcholine (PC) levels for $68 \mathrm{~d}$ (Mean values and standard deviations; $n$ )

\begin{tabular}{|c|c|c|c|c|c|c|c|c|c|c|c|c|}
\hline \multirow[b]{2}{*}{ Index } & \multicolumn{2}{|c|}{ G0 } & \multicolumn{2}{|c|}{ G0.25 } & \multicolumn{2}{|c|}{ G0.5 } & \multicolumn{2}{|c|}{ G1 } & \multicolumn{2}{|c|}{ G2 } & \multicolumn{2}{|c|}{ G4 } \\
\hline & Mean & SD & Mean & SD & Mean & SD & Mean & SD & Mean & SD & Mean & SD \\
\hline Initial weight (g) & 83.44 & $2 \cdot 40$ & 81.07 & 3.58 & 82.96 & 3.58 & 84.89 & $4 \cdot 73$ & 81.44 & 2.95 & $85 \cdot 60$ & $1 \cdot 15$ \\
\hline Final weight (g) & $268 \cdot 52$ & $10 \cdot 66$ & $264 \cdot 64$ & $9 \cdot 89$ & $270 \cdot 86$ & $2 \cdot 60$ & $277 \cdot 38$ & 18.91 & $265 \cdot 22$ & 12.53 & $267 \cdot 51$ & 1.63 \\
\hline Weight gain $(\%)^{*}$ & $225 \cdot 29^{a, b}$ & 5.02 & $226 \cdot 60^{a, b}$ & 8.85 & $233.66^{a}$ & 4.67 & $226 \cdot 59^{a, b}$ & $4 \cdot 22$ & $225 \cdot 60^{a, b}$ & 5.48 & $212 \cdot 55^{\mathrm{b}}$ & $4 \cdot 81$ \\
\hline Specific growth rate† & $1 \cdot 72^{\mathrm{a}, \mathrm{b}}$ & 0.03 & $1 \cdot 72^{a, b}$ & 0.01 & $1.77^{\mathrm{b}}$ & 0.02 & $1 \cdot 74^{\mathrm{b}}$ & 0.02 & $1 \cdot 74^{\mathrm{b}}$ & 0.02 & $1.67^{\mathrm{a}}$ & 0.02 \\
\hline Feed efficiency rate (\%)‡ & $82.95^{\mathrm{a}}$ & 1.45 & $88 \cdot 18^{\mathrm{b}, \mathrm{c}}$ & 0.53 & $88 \cdot 68^{c}$ & $1 \cdot 19$ & $94.86^{d}$ & $2 \cdot 82$ & $88.58^{c}$ & 0.43 & $85 \cdot 16^{a, b}$ & $1 \cdot 27$ \\
\hline Feeding rate $(\% / d) \S$ & $1 \cdot 81$ & 0.08 & $1 \cdot 81$ & 0.06 & $1 \cdot 76$ & 0.02 & $1 \cdot 75$ & 0.10 & 1.80 & 0.05 & $1 \cdot 81$ & 0.05 \\
\hline Hepatosomatic index (\%) $\|$ & $1.98^{\mathrm{a}}$ & 0.11 & $2 \cdot 04^{a}$ & 0.12 & $2 \cdot 60^{b}$ & 0.14 & $2 \cdot 64^{b}$ & 0.24 & $2.43^{\mathrm{b}}$ & 0.20 & $2 \cdot 08^{a}$ & 0.11 \\
\hline Viscerosomatic index (\%) & $9 \cdot 80^{a, b}$ & 0.87 & $9 \cdot 77^{\mathrm{a}, \mathrm{b}}$ & 0.63 & $10 \cdot 12^{a, b}$ & 0.78 & $10 \cdot 50^{\mathrm{b}}$ & 0.63 & $9 \cdot 71^{a, b}$ & 0.98 & $9 \cdot 33^{a}$ & 0.42 \\
\hline
\end{tabular}

a,b,c Mean values in the same row with unlike superscript letters were significantly different $(P<0.05)$

* Weight gain $(W G, \%)=100 \times$ (final body weight - initial body weight)/initial body weight.

† Specific growth ratio $(\mathrm{SGR}, \% / \mathrm{d})=100 \times \ln ($ final weight/initial weight)/d.

‡ Feed efficiency rate $(F E R, \%)=100 \times$ wet weight gain/dry feed consumed.

$\S$ Feeding rate $(F R)=100 \times$ dry feed consumed $\times 2 /($ final body weight + initial body weight $) / \mathrm{d}$.

|| Hepatosomatic index (HSI, \%) $=100 \times$ (hepatosomatic weight/whole body weight).

II Viscerosomatic index (VSI, \%) $=100 \times$ (viscera weight/whole body weight).

Table 5. Proximate tissues and whole-body compositions of Nile tilapia fed diets containing different levels of phosphatidylcholine (PC) for $68 \mathrm{~d}$ (\%) (wet mass)

(Mean values and standard deviations; $n 3$ )

\begin{tabular}{|c|c|c|c|c|c|c|c|c|c|c|c|c|}
\hline \multirow[b]{2}{*}{ Index } & \multicolumn{2}{|c|}{ G0 } & \multicolumn{2}{|c|}{ G0.25 } & \multicolumn{2}{|c|}{ G0.5 } & \multicolumn{2}{|c|}{ G1 } & \multicolumn{2}{|c|}{ G2 } & \multicolumn{2}{|c|}{ G4 } \\
\hline & Mean & $\mathrm{SD}$ & Mean & SD & Mean & SD & Mean & SD & Mean & SD & Mean & SD \\
\hline \multicolumn{13}{|l|}{ Whole body } \\
\hline Moisture & $67 \cdot 83$ & 0.22 & $67 \cdot 88$ & 0.70 & $68 \cdot 23$ & 0.51 & 68.63 & 0.37 & $68 \cdot 40$ & 0.86 & $68 \cdot 66$ & 0.84 \\
\hline Crude protein & $16 \cdot 32^{a}$ & 0.47 & $16 \cdot 21^{a}$ & 0.36 & $16 \cdot 31^{a}$ & 0.54 & $15 \cdot 41^{b}$ & 0.36 & $15 \cdot 93^{a, b}$ & 0.33 & $16 \cdot 06^{a}$ & 0.38 \\
\hline Crude fat & $10 \cdot 79^{a}$ & 0.43 & $10 \cdot 02^{b}$ & 0.51 & $10 \cdot 22^{b}$ & 0.41 & $10 \cdot 14^{b}$ & 0.43 & $9 \cdot 76^{\mathrm{b}}$ & 0.32 & $9 \cdot 77^{\mathrm{b}}$ & 0.42 \\
\hline Ash & 3.94 & 0.21 & 3.43 & 0.18 & 3.42 & 0.34 & 3.74 & 0.08 & 3.52 & 0.43 & $3 \cdot 81$ & 0.27 \\
\hline \multicolumn{13}{|l|}{ Muscle } \\
\hline Moisture & $77 \cdot 89$ & 0.54 & $77 \cdot 17$ & 0.752 & 76.59 & 0.46 & $76 \cdot 49$ & 0.23 & $76 \cdot 95$ & 0.74 & $76 \cdot 69$ & 0.47 \\
\hline Crude protein & $18 \cdot 88^{a}$ & 0.25 & $19 \cdot 54^{b}$ & 0.08 & $19 \cdot 41^{\mathrm{b}}$ & 0.43 & $19 \cdot 31^{b}$ & 0.39 & $19 \cdot 43^{b}$ & 0.39 & $19 \cdot 38^{b}$ & 0.21 \\
\hline Crude fat & $1.68^{a}$ & 0.12 & $1 \cdot 72^{\mathrm{a}}$ & 0.15 & $2 \cdot 18^{\mathrm{b}, \mathrm{c}}$ & 0.08 & $2 \cdot 32^{\mathrm{C}}$ & 0.29 & $1.98^{b}$ & 0.09 & $1.67^{a}$ & 0.13 \\
\hline Ash & $1 \cdot 31$ & 0.07 & $1 \cdot 32$ & 0.03 & $1 \cdot 30$ & 0.05 & $1 \cdot 27$ & 0.03 & $1 \cdot 27$ & 0.02 & $1 \cdot 27$ & 0.03 \\
\hline \multicolumn{13}{|l|}{ Liver } \\
\hline Moisture & $64 \cdot 97^{a}$ & 0.92 & $64 \cdot 44^{\mathrm{a}}$ & 1.04 & $64 \cdot 97^{a}$ & 0.34 & $64.58^{a}$ & 0.40 & $65 \cdot 27^{a}$ & 0.58 & $66 \cdot 68^{\mathrm{b}}$ & 0.73 \\
\hline Crude protein & $9 \cdot 89$ & 0.62 & 9.07 & 0.86 & 8.96 & 0.65 & $8 \cdot 78$ & 0.59 & 9.08 & 0.18 & 9.50 & 0.19 \\
\hline Crude fat & $10 \cdot 53^{a}$ & 0.61 & $10 \cdot 26^{a, b}$ & 0.39 & $9 \cdot 77^{\mathrm{b}, \mathrm{c}}$ & 0.76 & $9.92^{\mathrm{b}, \mathrm{c}}$ & 0.79 & $9 \cdot 77^{\mathrm{b}, \mathrm{c}}$ & 0.91 & $8 \cdot 34^{c}$ & 0.42 \\
\hline \multicolumn{13}{|l|}{ Viscera } \\
\hline Moisture & $61 \cdot 25$ & 0.92 & $59 \cdot 84$ & 1.08 & 59.51 & $1 \cdot 11$ & $60 \cdot 79$ & 0.72 & $60 \cdot 12$ & 1.01 & $61 \cdot 34$ & $2 \cdot 13$ \\
\hline Crude protein & $8 \cdot 71^{a}$ & 0.28 & $8 \cdot 70^{a}$ & 0.73 & $8 \cdot 29^{a, b}$ & 0.35 & $8 \cdot 30^{a, b}$ & 0.71 & $8.06^{a, b}$ & 0.51 & $7 \cdot 73^{b}$ & 0.53 \\
\hline Crude fat & $21.95^{a}$ & 1.06 & $21 \cdot 22^{a, b}$ & 0.45 & $21.50^{a, b}$ & 1.28 & $19 \cdot 85^{b}$ & 1.09 & $19 \cdot 51^{b}$ & 0.85 & $19 \cdot 26^{b}$ & $1 \cdot 14$ \\
\hline
\end{tabular}

a,b,c Mean values in the same row with unlike superscript letters were significantly different $(P<0.05)$. 
decreased to $1.67 \%$ when dietary PC increased further from 21.3 to $41 \mathrm{~g} / \mathrm{kg}$. Moisture concentrations in liver were significantly higher in the G4 group than in other groups $(P<0.05)$. Moisture concentrations in muscle, viscera and whole body were unchanged with increasing dietary PC levels. The G1 group had the lowest protein content in the whole body. With increasing dietary PC level, crude protein content in muscle in $\mathrm{PC}$-added groups significantly increased compared with fish fed the control diet $(P<0 \cdot 05)$. Liver protein content was not affected by dietary PC level. Increasing dietary PC levels resulted in crude protein content in viscera decreasing from 8.71 to $7.73 \%(P<0.05)$. No significant differences were found in the ash content of whole body or muscle.

\section{Phosphatidylcholine content of muscle and liver}

Fig. 1 shows the PC content of muscle and liver in fish fed different dietary levels of PC. The PC content in the liver increased with greater amounts of PC in the diet, becoming significantly higher in the G4 group than in the control group $(P<0.05)$. As dietary PC levels increased, the muscle content of $\mathrm{PC}$ in fish containing diets with added PC was not significantly different compared with that of the control group.

\section{Muscle and liver tissue fatty acid profile}

In muscle, there were differences in total SFA, MUFA and PUFA in response to dietary PC level (Table 6). SFA and MUFA increased, whereas PUFA decreased with increasing dietary PC levels. In particular, C16:0 and C18:1 increased with increasing dietary PC levels, whereas linoleic acid (C18:2n-6, LA) was significantly (Mean values and standard deviations; $n$ 3)
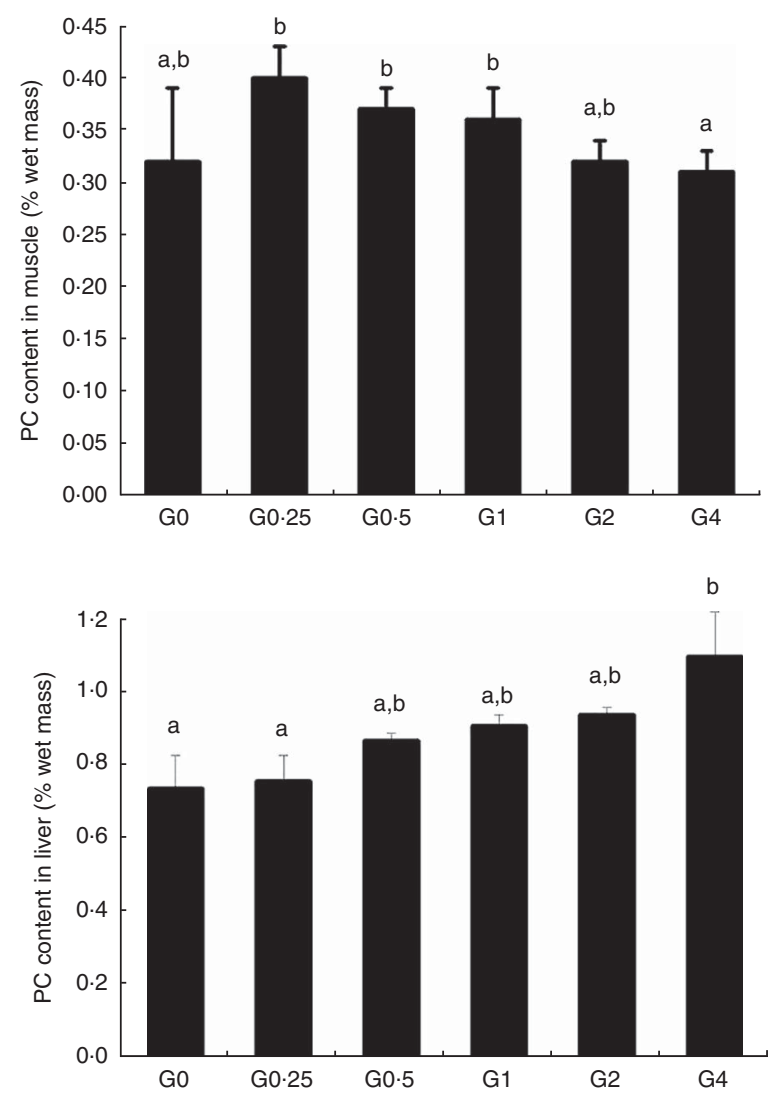

Fig. 1. Phosphatidylcholine (PC) content of muscle and liver in adult Nile tilapia fed diets containing different PC levels for $68 \mathrm{~d}$. Values are means, and standard deviations represented by vertical bars. ${ }^{\mathrm{a}, \mathrm{b}}$ Mean values with unlike letters were significantly different using Duncan's multiple-range test $(P<0.05)$.

Table 6. Fatty acid composition (\% of total fatty acids) of the muscle of Nile tilapia fed diets containing different phosphatidylcholine (PC) levels for $68 \mathrm{~d}$

\begin{tabular}{|c|c|c|c|c|c|c|c|c|c|c|c|c|}
\hline \multirow[b]{2}{*}{ Index } & \multicolumn{2}{|c|}{ G0 } & \multicolumn{2}{|c|}{ G0.25 } & \multicolumn{2}{|c|}{ G0.5 } & \multicolumn{2}{|c|}{ G1 } & \multicolumn{2}{|c|}{ G2 } & \multicolumn{2}{|c|}{ G4 } \\
\hline & Mean & SD & Mean & SD & Mean & SD & Mean & SD & Mean & SD & Mean & SD \\
\hline \multicolumn{13}{|l|}{ SFA } \\
\hline C14:0 & $2 \cdot 75^{a}$ & 0.07 & $2 \cdot 84^{a}$ & 0.14 & $3.51^{\mathrm{b}}$ & 0.21 & $3.56^{\mathrm{b}}$ & 0.09 & $3.68^{b}$ & 0.06 & $3.70^{\mathrm{b}}$ & 0.06 \\
\hline C16:0 & $19.96^{a}$ & 1.09 & $22 \cdot 28^{\mathrm{c}}$ & 0.82 & $20 \cdot 19^{a, b}$ & 0.89 & $22 \cdot 04^{b, c}$ & 0.27 & $22 \cdot 94^{\mathrm{c}}$ & 0.31 & $23.91^{\mathrm{C}}$ & 0.52 \\
\hline C18:0 & $17 \cdot 37^{a}$ & 0.98 & $21 \cdot 22^{b}$ & 0.94 & $21 \cdot 10^{\mathrm{b}}$ & 0.59 & $16 \cdot 91^{a}$ & 0.98 & $16 \cdot 55^{\mathrm{a}}$ & 0.66 & $18 \cdot 73^{a}$ & 0.53 \\
\hline C20: 0 & 1.41 & 0.04 & 1.51 & 0.05 & 1.53 & 0.06 & 1.51 & 0.02 & 1.50 & 0.18 & 1.43 & 0.06 \\
\hline \multicolumn{13}{|l|}{ MUFA } \\
\hline C14:1 & 0.18 & 0.06 & 0.19 & 0.04 & 0.18 & 0.06 & 0.19 & 0.06 & 0.30 & 0.06 & 0.21 & 0.03 \\
\hline C16:1 & $5 \cdot 71^{\mathrm{a}}$ & 0.37 & $5 \cdot 78^{\mathrm{a}}$ & 0.23 & $6 \cdot 20^{\mathrm{a}, \mathrm{b}}$ & 0.33 & $6 \cdot 88^{b}$ & 0.42 & $6.97^{b}$ & 0.25 & $6 \cdot 69^{b}$ & 0.18 \\
\hline C18: 1 & $26 \cdot 81^{a}$ & 0.71 & $26 \cdot 73^{a}$ & 0.53 & $26 \cdot 08^{a}$ & 0.25 & $30 \cdot 31^{b}$ & 0.55 & $31 \cdot 11^{b}$ & 0.83 & $29.56^{b}$ & 0.69 \\
\hline \multicolumn{13}{|l|}{$n-6$} \\
\hline C18:2 & $16 \cdot 32^{\mathrm{e}}$ & 0.55 & $12 \cdot 11^{\mathrm{c}, \mathrm{d}}$ & 0.68 & $13 \cdot 57^{d}$ & 0.70 & $11.41^{\mathrm{b}, \mathrm{c}}$ & 0.81 & $10 \cdot 23^{a, b}$ & 0.38 & $9.39^{a}$ & 0.66 \\
\hline $\mathrm{C} 18: 3$ & $1.06^{a}$ & 0.09 & $0.80^{b}$ & 0.04 & $0.92^{\mathrm{a}, \mathrm{b}}$ & 0.04 & $0.86^{a, b}$ & 0.13 & $0.73^{b, c}$ & 0.09 & $0.64^{c}$ & 0.09 \\
\hline C20: 4 & 1.47 & 0.20 & $1 \cdot 70$ & 0.15 & 1.69 & 0.12 & 1.37 & 0.09 & $1 \cdot 37$ & 0.13 & 1.43 & $0 \cdot 10$ \\
\hline \multicolumn{13}{|l|}{$n-3$} \\
\hline C18:3 & $1.07^{\mathrm{a}}$ & 0.05 & $0.81^{b}$ & 0.06 & $0.84^{\mathrm{b}}$ & 0.04 & $0.76^{\mathrm{b}, \mathrm{c}}$ & 0.04 & $0.64^{\mathrm{C}}$ & 0.04 & $0.51^{d}$ & 0.04 \\
\hline C18:4 & 0.15 & 0.02 & 0.11 & 0.02 & 0.10 & 0.02 & 0.13 & 0.02 & 0.12 & 0.02 & 0.11 & 0.01 \\
\hline $\mathrm{C} 20: 5$ & $1 \cdot 21^{a}$ & 0.03 & $1.04^{a}$ & 0.15 & $0.95^{\mathrm{a}, \mathrm{b}}$ & 0.05 & $0.91^{b}$ & 0.08 & $0.89^{b}$ & 0.04 & $0.98^{\mathrm{b}}$ & 0.10 \\
\hline C22: 6 & 0.57 & 0.02 & 0.59 & 0.02 & 0.51 & 0.05 & 0.52 & 0.08 & 0.45 & 0.08 & 0.50 & 0.07 \\
\hline Total SFA & $41.49^{a}$ & 0.51 & $47.86^{c}$ & 0.45 & $46 \cdot 34^{\mathrm{b}, \mathrm{c}}$ & 0.62 & $44.02^{b}$ & $1 \cdot 16$ & $44 \cdot 68^{b}$ & 1.05 & $47.78^{\mathrm{C}}$ & 1.07 \\
\hline Total MUFA & $32 \cdot 70^{a}$ & 1.05 & $32 \cdot 70^{\mathrm{a}}$ & 0.37 & $32 \cdot 46^{\mathrm{a}}$ & 0.38 & $37 \cdot 38^{b}$ & 0.75 & $38.39^{b}$ & 0.63 & $36 \cdot 46^{\mathrm{b}}$ & 0.82 \\
\hline Total PUFA & $21.85^{\mathrm{e}}$ & 0.62 & $17 \cdot 15^{\mathrm{c}, \mathrm{d}}$ & 0.48 & $18.59^{d}$ & 0.74 & $15.96^{b, c}$ & 0.87 & $14.43^{a, b}$ & 0.59 & $13.56^{a}$ & $0 \cdot 70$ \\
\hline Total $n-6$ & $18.85^{\mathrm{e}}$ & 0.60 & $14.62^{\mathrm{c}, \mathrm{d}}$ & 0.53 & $16 \cdot 18^{\mathrm{d}}$ & 0.64 & $13.64^{b, c}$ & 0.85 & $12 \cdot 33^{a, b}$ & 0.60 & $11.46^{\mathrm{a}}$ & 0.62 \\
\hline Total $n-3$ & $3.00^{C}$ & 0.07 & $2.53^{\mathrm{b}}$ & 0.09 & $2 \cdot 40^{\mathrm{a}, \mathrm{b}}$ & 0.13 & $2 \cdot 33^{a, b}$ & 0.02 & $2 \cdot 11^{\mathrm{a}}$ & 0.16 & $2 \cdot 11^{a}$ & 0.22 \\
\hline
\end{tabular}

a,b,c,d,e Mean values in the same row with unlike superscript letters were significantly different $(P<0.05)$. 
decreased in muscle from the higher PC groups, with the G4 group containing $57 \%$ less LA than the control group $(P<0.05)$.

SFA in the liver decreased from 29.27 to $27.88 \%(P<0.05)$ as dietary PC levels increased from 1.7 to $6.5 \mathrm{~g} / \mathrm{kg}$, and then increased to $31.53 \%$ as dietary PC increased to $41 \mathrm{~g} / \mathrm{kg}$. No significant differences were obtained in MUFA and PUFA content in fish fed additional PC compared with the control group (Table 7).

Table 7. Fatty acid composition (\% of total fatty acids) of the liver of Nile tilapia fed diets containing different phosphatidylcholine (PC) levels for $68 \mathrm{~d}$ (\%) (Mean values and standard deviations; $n 3$ )

\begin{tabular}{|c|c|c|c|c|c|c|c|c|c|c|c|c|}
\hline \multirow[b]{2}{*}{ Index } & \multicolumn{2}{|c|}{ G0 } & \multicolumn{2}{|c|}{ G0.25 } & \multicolumn{2}{|c|}{ G0.5 } & \multicolumn{2}{|c|}{ G1 } & \multicolumn{2}{|c|}{ G2 } & \multicolumn{2}{|c|}{ G4 } \\
\hline & Mean & SD & Mean & SD & Mean & SD & Mean & SD & Mean & SD & Mean & SD \\
\hline \multicolumn{13}{|l|}{ SFA } \\
\hline C14:0 & $1.93^{a}$ & 0.07 & $1.99^{a, b}$ & 0.03 & $2 \cdot 19^{\mathrm{a}, \mathrm{b}, \mathrm{c}}$ & 0.19 & $2 \cdot 17^{\mathrm{a}, \mathrm{b}, \mathrm{c}}$ & 0.12 & $2 \cdot 28^{\mathrm{b}, \mathrm{c}}$ & 0.12 & $2 \cdot 44^{c}$ & 0.10 \\
\hline C16:0 & $20 \cdot 42^{a, b}$ & 0.04 & $19 \cdot 81^{a}$ & 0.21 & $19 \cdot 59^{a}$ & 0.74 & $20 \cdot 23^{a, b}$ & 0.30 & $21 \cdot 37^{b}$ & 0.37 & $22 \cdot 67^{c}$ & 0.51 \\
\hline C18:0 & 5.53 & 034 & $5 \cdot 22$ & 0.41 & 4.69 & 0.38 & 4.89 & 0.10 & $5 \cdot 11$ & 0.29 & $5 \cdot 16$ & 0.29 \\
\hline C20: 0 & $1.39^{\mathrm{b}}$ & 0.06 & $1 \cdot 18^{a}$ & 0.02 & $1.41^{\mathrm{b}}$ & 0.10 & $1 \cdot 21^{a}$ & 0.07 & $1 \cdot 39^{b}$ & 0.03 & $1 \cdot 26^{a, b}$ & 0.05 \\
\hline \multicolumn{13}{|l|}{ MUFA } \\
\hline C14: 1 & 0.26 & 0.06 & 0.28 & 0.08 & 0.23 & 0.02 & 0.22 & 0.02 & 0.21 & 0.03 & 0.18 & 0.03 \\
\hline C16: 1 & $3 \cdot 37^{a}$ & 0.19 & $3.46^{\mathrm{a}}$ & 0.13 & $3 \cdot 74^{a, b}$ & 0.16 & $4.04^{\mathrm{b}, \mathrm{c}}$ & 0.14 & $4.09^{b, c}$ & 0.07 & $4 \cdot 32^{c}$ & 0.18 \\
\hline C18: 1 & 30.98 & 0.88 & 31.37 & 0.64 & $31 \cdot 23$ & 1.70 & 30.97 & $1 \cdot 10$ & 30.29 & 1.02 & 30.62 & 0.25 \\
\hline \multicolumn{13}{|l|}{$n-6$} \\
\hline C18:2 & $23 \cdot 30^{b}$ & 0.46 & $24 \cdot 19^{b}$ & 0.83 & $23 \cdot 83^{b}$ & $1 \cdot 27$ & $22 \cdot 39^{a, b}$ & 0.12 & $23 \cdot 14^{b}$ & 0.31 & $20 \cdot 59^{a}$ & 0.76 \\
\hline C18:3 & $1.05^{a, b}$ & 0.05 & $1 \cdot 31^{\mathrm{c}}$ & 0.12 & $1 \cdot 22^{b, c}$ & 0.08 & $1 \cdot 21^{\mathrm{b}, \mathrm{c}}$ & 0.03 & $1.04^{a, b}$ & 0.08 & $0.88^{a}$ & 0.02 \\
\hline $\mathrm{C} 20: 4$ & $3.00^{b}$ & 0.20 & $2 \cdot 50^{a}$ & 0.22 & $2 \cdot 82^{a, b}$ & 0.26 & $3 \cdot 22^{b}$ & 0.16 & $2 \cdot 89^{a}$ & 0.12 & $3.06^{a, b}$ & 0.15 \\
\hline \multicolumn{13}{|l|}{$n-3$} \\
\hline C18:3 & $1.49^{b, c}$ & 0.12 & $1 \cdot 84^{d}$ & 0.04 & $1 \cdot 71^{c, d}$ & 0.14 & $1.56^{b, c}$ & 0.04 & $1.46^{\mathrm{b}}$ & 0.01 & $1 \cdot 22^{a}$ & 0.03 \\
\hline $\mathrm{C} 20: 5$ & $2 \cdot 18^{b}$ & 0.15 & $1.78^{a}$ & 0.03 & $1 \cdot 85^{a, b}$ & 0.12 & $2.07^{a, b}$ & 0.14 & $1.99^{a, b}$ & 0.09 & $2 \cdot 14^{\mathrm{b}}$ & 0.19 \\
\hline $\mathrm{C} 22: 6$ & $1 \cdot 20$ & 0.06 & 1.00 & 0.08 & $1 \cdot 11$ & 0.10 & $1 \cdot 19$ & 0.07 & $1 \cdot 10$ & 0.17 & $1 \cdot 18$ & 0.03 \\
\hline Total SFA & $29 \cdot 27^{b, c}$ & 0.44 & $28 \cdot 21^{a, b}$ & 0.64 & $27 \cdot 88^{a}$ & 0.61 & $28.51^{a, b}$ & 0.20 & $30 \cdot 13^{c}$ & 0.40 & $31.53^{d}$ & 0.53 \\
\hline Total MUFA & 34.51 & 0.96 & $35 \cdot 11$ & 0.55 & $35 \cdot 21$ & 1.67 & $35 \cdot 22$ & 1.09 & 34.49 & 0.96 & 35.09 & 0.06 \\
\hline Total PUFA & $32 \cdot 23^{a, b}$ & 0.62 & $32 \cdot 23^{a, b}$ & $1 \cdot 19$ & $32.55^{\mathrm{b}}$ & 1.62 & $31 \cdot 63^{a, b}$ & 0.30 & $31.63^{a, b}$ & 0.69 & $29 \cdot 06^{a}$ & 0.93 \\
\hline Total $n-6$ & $27 \cdot 36^{b}$ & 0.64 & $28 \cdot 01^{\mathrm{b}}$ & $1 \cdot 10$ & $27 \cdot 88^{b}$ & 1.49 & $26 \cdot 81^{a, b}$ & 0.24 & $27 \cdot 08^{b}$ & 0.50 & $24 \cdot 53^{a}$ & 0.90 \\
\hline Total $n-3$ & 4.87 & 0.12 & 4.63 & 0.09 & $4 \cdot 67$ & 0.13 & 4.82 & 0.20 & 4.55 & 0.19 & 4.53 & 0.20 \\
\hline
\end{tabular}

a,b,c,d Mean values in the same row with unlike superscript letters were significantly different $(P<0.05)$.
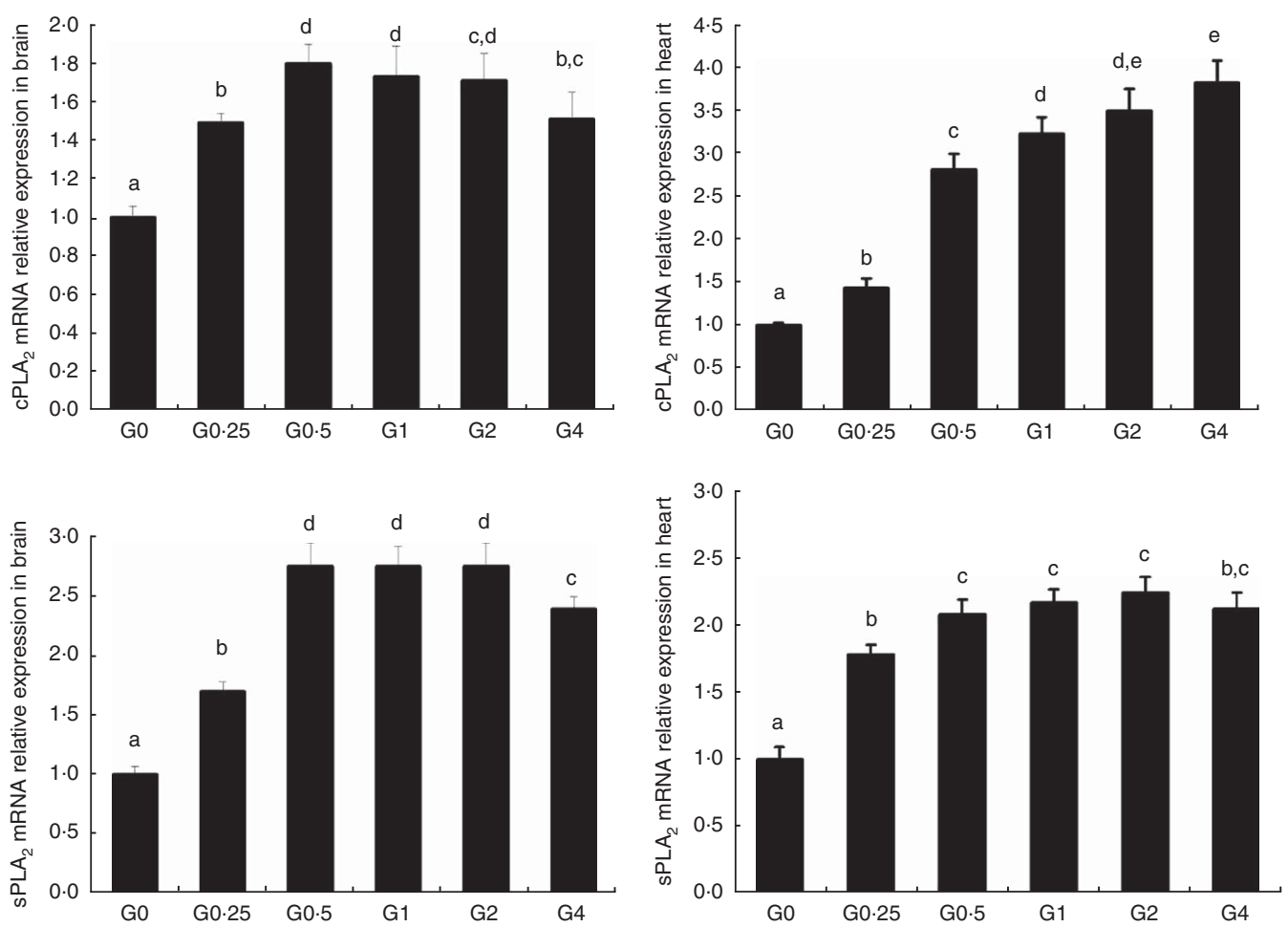

Fig. 2. The effects of dietary phosphatidylcholine (PC) levels on the mRNA expression levels of phospholipase $A_{2}\left(P L A_{2}\right)$ in brain and heart for adult Nile tilapia. Values are means, and standard deviations represented by vertical bars. $c P L A_{2}$ : cytosolic phospholipase $A_{2}$; sPLA $A_{2}$, secretory phospholipase $A_{2}$. ${ }^{a}, b, c, d, e$ Mean values with unlike letters were significantly different using Duncan's multiple-range test $(P<0.05)$. 


\section{Relative mRNA expression levels}

The expression of $c P L A_{2}$ and $S P L A_{2}$ mRNA was up-regulated in brain and heart with increased dietary PC levels compared with the control diet group without added PC (Fig. 2). Increased dietary PC reduced FAS mRNA expression in the liver and FAS mRNA expression in visceral tissue was reduced from the G0.5 to the G4 group. In contrast, FAS mRNA expression increased in the muscle from the G0.5 to the G4 group (Fig. 3(A)). In the PC-fed groups, there was a significant up-regulation in $L P L$ mRNA expression in liver and visceral tissue $(P<0.05)$, and down-regulation in muscle $(P<0 \cdot 05)$ (Fig. 3(B)). Compared with the control group, the PC-fed groups showed higher HSL mRNA levels in the liver (from the G0.5 to the G4 group) and visceral tissue (from the G1 to the G4 group). However, HSL mRNA levels in muscle were significantly lower in the PC-fed fish than in the control group $(P<0.05)$ (Fig. 3(C)). GH mRNA in brain was significantly down-regulated with $\mathrm{PC}$ levels of $6.5 \mathrm{~g} / \mathrm{kg}$ or above $(P<0.05)$, whereas $I G F-1 \mathrm{mRNA}$ in liver was significantly down-regulated at a PC level above $6.5 \mathrm{~g} / \mathrm{kg}$ $(P<0.05)$ (Fig. 4).

\section{Discussion}

The weight gain and specific growth rate for adult Nile tilapia remained largely unchanged by the addition of $\mathrm{PC}$ to the diet. This suggests that adult tilapia do not require additional PC for normal growth performance, which is consistent with previous results in juvenile large yellow croaker ${ }^{(31)}$, Atlantic salmon ${ }^{(10)}$ and white sturgeon $^{(4)}$. We measured the mRNA expression of GH in the brain and expression of $I G F-1$ in liver, as the GH/IGF axis senses nutritional status and regulates body growth ${ }^{(32)}$, and $G H$ and $I G F-1$ mRNA are abundantly expressed in brain ${ }^{(33)}$ and liver ${ }^{(34)}$ in tilapia. The expression of $G H$ mRNA in the brain and $I G F-1$ mRNA in liver were down-regulated with higher levels of $\mathrm{PC}$ in the diet. This indicates that high levels of dietary PC reduce $G H$ and $I G F$ expression, potentially inhibiting the secretion of $\mathrm{GH}$, and resulting in relatively slow growth performance.

As dietary PC levels increased, the crude fat content decreased in the whole body, liver and viscera, whereas PC content increased, indicating that dietary PC can reduce lipid accumulation in adult tilapia by regulating lipid metabolism. This is in agreement with previous results in large yellow croaker ${ }^{(31,35)}$ and
(A)
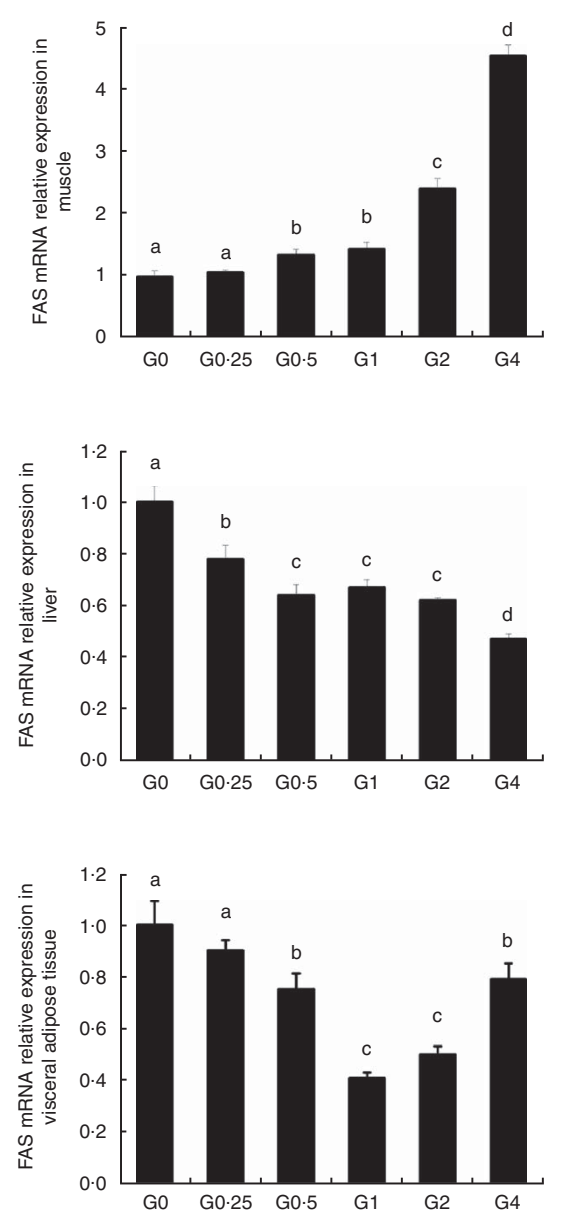

(B)
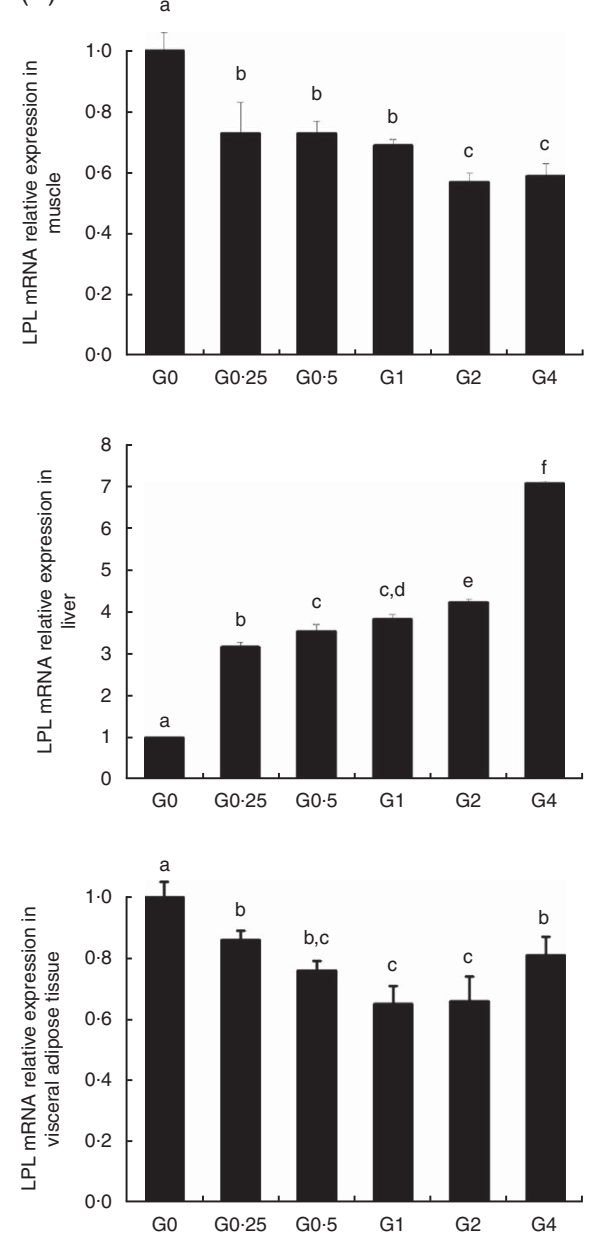

(C)
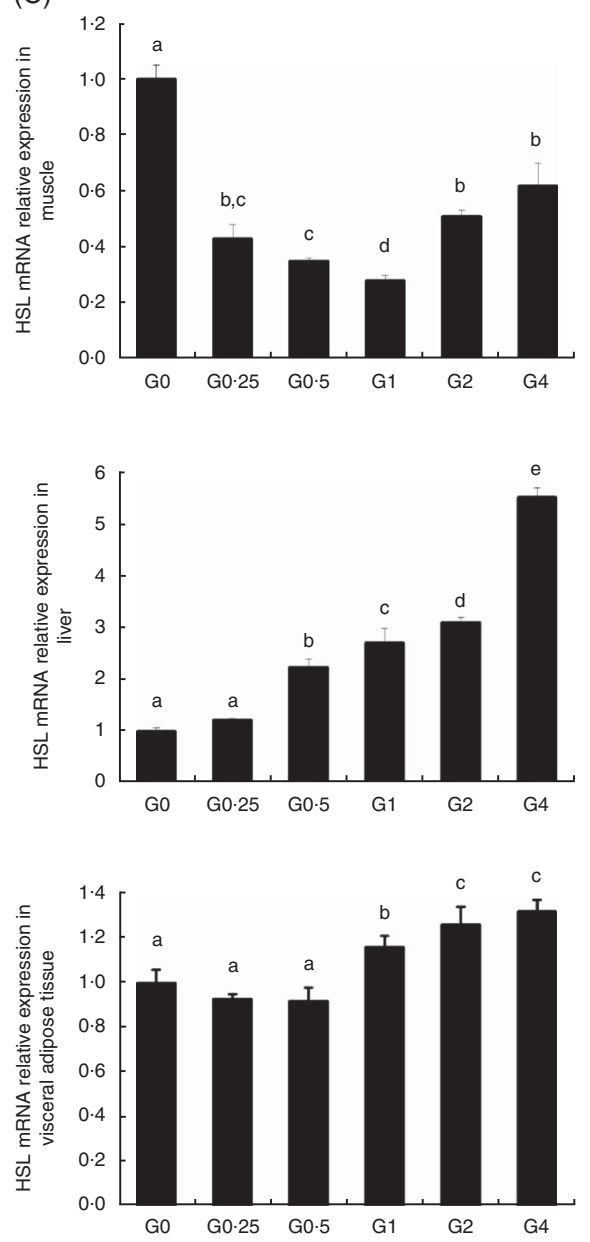

Fig. 3. The effects of dietary phosphatidylcholine (PC) levels on the mRNA expression levels of genes involved in lipid metabolism in adult Nile tilapia for $68 \mathrm{~d}$. (A) Fatty acid synthase (FAS) mRNA relative expression in liver, muscle and visceral adipose tissues. (B) Lipoprotein lipase (LPL) mRNA expression in liver, muscle and visceral adipose tissues. (C) Hormone-sensitive lipase (HSL) mRNA expression in liver, muscle and visceral adipose tissues. Values are means, and standard deviations represented by vertical bars. ${ }^{\mathrm{a}, \mathrm{b}, \mathrm{c}, \mathrm{d}, \mathrm{e}, \mathrm{f}}$ Mean values with unlike letters were significantly different using Duncan's multiple-range test $(P<0 \cdot 05)$. 

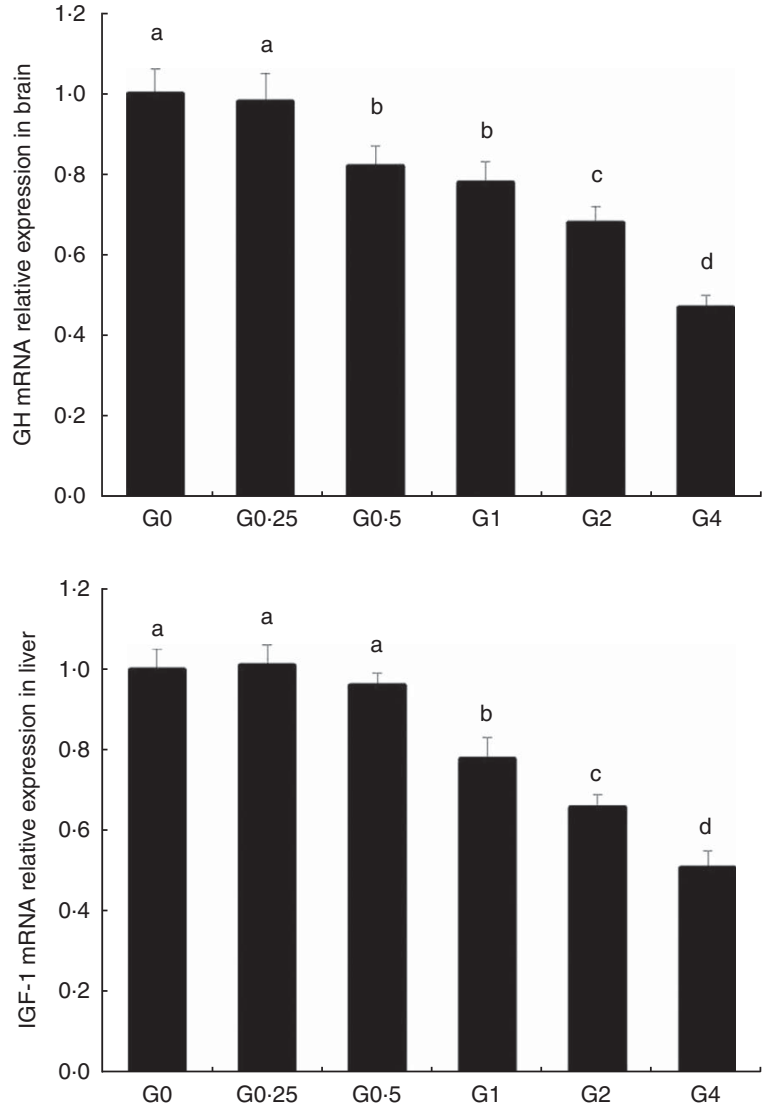

Fig. 4. The effects of dietary phosphatidylcholine (PC) levels on the mRNA expression levels of genes involved in growth hormone $(G H)$ and insulin-like growth factor-1 (IGF-1) in adult Nile tilapia for $68 \mathrm{~d}$. Values are means, and standard deviations represented by vertical bars. ${ }^{a}, \mathrm{~b}, \mathrm{c}, \mathrm{d}$ Mean values with unlike letters were significantly different using Duncan's multiple-range test $(P<0.05)$.

Dojo loach ${ }^{(36)}$, which suggest that PL may prevent and alleviate signs of liver disease in fish. We hypothesised that for fish fed diets with PC, the expression of genes related to lipogenesis would be lower, and the expression of genes related to lipolysis would be higher, ultimately resulting in lower lipid content. We investigated the effect of increased dietary PC on the expression of lipogenesis-related genes. PC increased the expression of LPL and HSL, enzymes involved in lipolysis, and decreased the expression of FAS, a lipogenic enzyme, in the liver. The level of $L P L$ expression in a given tissue is the rate-limiting process for the uptake of TAG-derived FA ${ }^{(37)}$. LPL activity has previously been reported to be higher in the liver of cobia supplemented with $\mathrm{PL}^{(38)}$, and expression of $L P L$ mRNA in the whole larval body significantly increased and expression of FAS mRNA decreased with the increasing levels of dietary PL in large yellow croaker larvae ${ }^{(39)}$. The expression of hepatic FAS mRNA was also decreased by diets with soyabean PL or EPA (EPA)-enriched PL in mice ${ }^{(12)}$. Our results confirm these previous findings, suggesting that PC increases the capacity to mobilise fat stores via regulation of competing lipolysis and lipogenesis enzymes, and these are consistent with the reduced lipid accumulation in the livers of Nile tilapia supplemented with PC. Unexpectedly, the higher dietary PC reduced expression of LPL and HSL in muscle, suggesting increased lipid deposition in muscle.
The fatty acid profiles in muscle and liver were affected by increasing PC levels, with SFA and MUFA increased and PUFA decreased in muscle. This may be related to variations in the fatty acid composition of the diets. Similarly, in Dojo loach, concentrations of total $n-3$ fatty acids in the whole body significantly decreased with incremental dietary PL levels ${ }^{(36)}$. In contrast, rainbow trout fry fed egg lecithin containing high levels of EPA and DHA showed higher amounts of PUFA than soyabean lecithin and soyabean oil control groups ${ }^{(40)}$. Fatty acids are released from membrane PL by the action of $\mathrm{PLA}_{2}$, of which two main types are present. CPLA 2 are soluble in the cytosol and must first interact with or penetrate the organised lipid interface. $\mathrm{sLA}_{2}$ are linked to the cell membrane and, as a consequence, are unlikely to be structured such that penetration of the lipid interface is physiologically relevant ${ }^{(23)} ; \mathrm{sPLA}_{2}$ is highly expressed in the pancreas, brain, heart and liver tissues ${ }^{(41)}$. Nalefski et al $^{\left({ }^{(42)}\right.}$ first cloned the complementary DNA sequence of $\mathrm{CPLA}_{2}$ from fish, and the $\mathrm{CPLA}_{2}$ protein from the zebrafish shares a low (65\%) similarity with that from humans. The activity of $\mathrm{SPLA}_{2}$ in Atlantic cod was higher in liver, brain, kidney and gills than in muscle, potentially because of the regulatory roles that $\mathrm{PLA}_{2}$ are thought to play in the brain and heart ${ }^{(43)}$. The expression of $s P L A_{2}$ mRNA in the whole body was positively correlated with dietary PL content in sea bass larvae ${ }^{(44)}$, and $\mathrm{SPLA}_{2}$ activity in red drum Sciaenops ocellatus larvae also increased with increasing dietary $\mathrm{PL}^{(45)}$. In this study, we noted an up-regulation of $c P L A_{2}$ and $S P L A_{2}$ mRNA expression with increasing dietary PC levels in the brain and heart, suggesting that $\mathrm{PLA}_{2}$ are potentially regulated via a positive feedback mechanism regulating the use of dietary PL in some fish.

\section{Conclusions}

Moderate supplementation of the diet with PC was beneficial for improving feed efficiency and reducing liver fat for adult Nile tilapia, with no effect on weight gain. Excessive dietary PC may alter the expression of $L P L, H S L$ and FAS mRNA in liver. Dietary supplementation with PC represents a potential new dietary approach to reduce feed requirements and improve the health of adult Nile tilapia in commercial aquaculture.

\section{Acknowledgements}

This work was supported by the China Agriculture Research System (grant no. CARS-46) and the Central Public-interest Scientific Institution Basal Research Fund (CAFS) (grant no. 2017JBF0204). These funders had no role in the design and analysis of the study, or in the writing of this article.

H. W. and J. T. designed the research; J. T., L.-J. Y., X. L., W. L., F. W. and C.-G. Y. conducted the experiments and analysed the data; J. T. and M. J. wrote the paper. All authors have read and approved the final manuscript.

The authors declare that there are no conflicts of interest.

\section{References}

1. Coutteau P, Geurden I, Camara MR, et al. (1997) Review on the dietary effects of phospholipids in fish and crustacean larviculture. Aquaculture 155, 149-164. 
2. Tocher DR, Bendiksen EA, Campbell PJ, et al. (2008) The role of phospholipids in nutrition and metabolism of teleost fish. Aquaculture 280, 21-34.

3. Koven WM, Parra G, Kolkovski S, et al. (1998) The effect of dietary phosphatidylcholine and its constituent fatty acids on microdiet ingestion and fatty acid absorption rate in gilthead sea bream, Sparus auratus, larvae. Aquacult Nutr 4, 39-45.

4. Hung SSO, Berge GM \& Storebakken T (1997) Growth and digestibility effects of soya lecithin and choline chloride on juvenile Atlantic salmon. Aquacult Nutr 3, 141-144.

5. Kasper CS \& Brown PB (2003) Growth improved in juvenile Nile tilapia fed phosphatidylcholine. $N$ Am J Aquacult 65 , 39-43.

6. Hadas E, Koven W, Sklan D, et al. (2003) The effect of dietary phosphatidylcholine on the assimilation and distribution of ingested free oleic acid (18:1n-9) in gilthead seabream (Sparus aurata) larvae. Aquaculture 217, 577-588.

7. Fontagné S, Geurden I, Escaffre A-M, et al. (1998) Histological changes induced by dietary phospholipids in intestine and liver of common carp (Cyprinus carpio L.) larvae. Aquaculture 161, 213-223.

8. Olsen RE, Tore Dragnes B, Myklebust R, et al. (2003) Effect of soybean oil and soybean lecithin on intestinal lipid composition and lipid droplet accumulation of rainbow trout, Oncorhynchus mykiss Walbaum. Fish Physiol Biochem 29, 181-192.

9. Hung SSO \& Lutes PB (1988) A preliminary study on the non-essentiality of lecithin for hatchery-produced juvenile white sturgeon (Acipenser transmontanus). Aquaculture $\mathbf{6 8}$, 353-360.

10. Poston HA (1990) Effect of body size on growth, survival, and chemical composition of Atlantic salmon fed soy lecithin and choline. Prog Fish Cult 52, 226-230.

11. Ipatova OM, Prozorovskaia NN, Torkhovskaia TI, et al. (2004) Biological effects of the soybean phospholipids. Biomed Khim 50, 436-450.

12. Liu X, Xue Y, Liu C, et al. (2013) Eicosapentaenoic acid-enriched phospholipid ameliorates insulin resistance and lipid metabolism in diet-induced-obese mice. Lipids Health Dis 12, 109.

13. Lee HS, Nam Y, Chung YH, et al. (2014) Beneficial effects of phosphatidylcholine on high-fat diet-induced obesity, hyperlipidemia and fatty liver in mice. Life Sci 118, 7-14.

14. Du Z (2014) Causes of fatty liver in farmed fish: a review and new perspectives. J Fisheries Chin 38, 1628-1638.

15. Weil C, Lefèvre F \& Bugeon J (2012) Characteristics and metabolism of different adipose tissues in fish. Rev Fish Biol Fisheries, 1-17.

16. Coutteau P, Camara MR \& Sorgeloos P (1996) The effect of different levels and sources of dietary phosphatidylcholine on the growth, survival, stress resistance, and fatty acid composition of postlarval Penaeus vannamei. Aquaculture 147, 261-273.

17. Sandel E, Nixon O, Lutzky S, et al. (2010) The effect of dietary phosphatidylcholine/phosphatidylinositol ratio on malformation in larvae and juvenile gilthead sea bream (Sparus aurata). Aquaculture 304, 42-48.

18. Geurden I \& Kaushik SG (2008) Dietary phosphatidylcholine affects postprandial plasma levels and digestibility of lipid in common carp (Cyprinus carpio). Br J Nutr 100, 512-517.

19. Sotoudeh E, Kenari AA \& Rezaei MH (2011) Growth response, body composition and fatty acid profile of Caspian brown trout (Salmo trutta Caspius) juvenile fed diets containing different levels of soybean phosphatidylcholine. Aquacult Int 19, 611-623.

20. Albalat A, Sánchez-Gurmaches J, Gutiérrez J, et al. (2006) Regulation of lipoprotein lipase activity in rainbow trout (Oncorhynchus mykiss) tissues. Gen Comp Endocr 146, 226-235.
21. Lampidonis AD, Rogdakis E, Voutsinas GE, et al. (2011) The resurgence of hormone-sensitive lipase (HSL) in mammalian lipolysis. Gene 477, 1-11.

22. Wakil SJ (1989) Fatty acid synthase, a proficient multifunctional enzyme. Biochemistry 28, 4523-4530.

23. Boulanger Y, Labelle M \& Khiat A (2000) Role of phospholipase $\mathrm{A}(2)$ on the variations of the choline signal intensity observed by $1 \mathrm{H}$ magnetic resonance spectroscopy in brain diseases. Brain Res Rev 33, 380-389.

24. Shirouchi B, Nagao K, Inoue N, et al. (2007) Effect of dietary omega 3 phosphatidylcholine on obesity-related disorders in Obese Otsuka Long-Evans Tokushima fatty rats. J Agric Food Chem 55, 7170-7176.

25. Won TJ, Nam Y, Lee HS, et al. (2013) Injection of phosphatidylcholine and deoxycholic acid regulates gene expression of lipolysis-related factors, pro-inflammatory cytokines, and hormones on mouse fat tissue. Food Chem Toxicol 60 , 263-268.

26. Robichaud JC, van der Veen JN, Yao Z, et al. (2009) Hepatic uptake and metabolism of phosphatidylcholine associated with high density lipoproteins. Biochim Biophys Acta 1790, 538-551.

27. Li SF, Tang SJ \& Cai WQ (2010) RAPD-SCAR markers for genetically improved new GIFT Nile tilapia (Oreochromis niloticus niloticus L.) and their application in strain identification. Dongwuxue Yanjiu 31, 147-154.

28. Hafedh YSA (1999) Effects of dietary protein on growth and body composition of Nile tilapia, Oreochromis niloticus L. Aquacult Res 30, 385-393.

29. Tian J, Wu F, Yang CG, et al. (2015) Dietary lipid levels impact lipoprotein lipase, hormone-sensitive lipase, and fatty acid synthetase gene expression in three tissues of adult GIFT strain of Nile tilapia, Oreochromis niloticus. Fish Physiol Biochem 41, 1-18.

30. Liu X, Liu H, Chen Y, et al. (2008) Effects of organic matter and initial carbon-nitrogen ratio on the bioconversion of volatile fatty acids from sewage sludge. J Chem Technol Biotechnol 83, 1049-1055.

31. Feng S, Cai Z, Zuo R, et al. (2017) Effects of dietary phospholipids on growth performance and expression of key genes involved in phosphatidylcholine metabolism in larval and juvenile large yellow croaker, Larimichthys crocea. Aquaculture 469, 59-66.

32. Reindl KM \& Sheridan MA (2012) Peripheral regulation of the growth hormone-insulin-like growth factor system in fish and other vertebrates. Comp Biochem Physiol A Mol Integr Physiol 163, 231-245.

33. Ma XL, Zhang Y, Huang WR, et al. (2006) cDNA cloning of growth hormone,growth hormone receptor and the different expression between male and female Nile tilapia Oreochromis niloticus. Acta Zool Sinica 52, 924-933.

34. Schmid AC, Lutz I, Kloas W, et al. (2003) Thyroid hormone stimulates hepatic IGF-I mRNA expression in a bony fish, the tilapia Oreochromis mossambicus, in vitro and in vivo. Gen Comp Endocrinol 130, 129-134.

35. Zhao J, Ai Q, Mai K, et al. (2013) Effects of dietary phospholipids on survival, growth, digestive enzymes and stress resistance of large yellow croaker, Larmichthys crocea larvae. Aquaculture 410-411, 122-128.

36. Gao J, Koshio S, Wang W, et al. (2014) Effects of dietary phospholipid levels on growth performance, fatty acid composition and antioxidant responses of Dojo loach Misgurnus anguillicaudatus larvae. Aquaculture 426-427, 304-309.

37. Merkel M, Weinstock PH, Chajek-Shaul T, et al. (1998) Lipoprotein lipase expression exclusively in liver. A mouse model for metabolism in the neonatal period and during cachexia. J Clin Invest 102, 893-901. 
38. Niu J, Liu YJ, Tian LX, et al. (2008) Effects of dietary phospholipid level in cobia (Rachycentron canadum) larvae: growth, survival, plasma lipids and enzymes of lipid metabolism. Fish Physiol Biochem 34, 9-17.

39. Cai Z, Feng S, Xiang X, et al. (2016) Effects of dietary phospholipid on lipase activity, antioxidant capacity and lipid metabolism-related gene expression in large yellow croaker larvae (Larimichthys crocea). Comp Biochem Physiol B Biochem Mol Biol 201, 46-52.

40. Azarm HM, Abedian-Kenari A \& Hedayati M (2013) Growth response and fatty acid composition of rainbow trout (Oncorbynchus mykiss) fry fed diets containing different levels of soybean and egg lecithin. Aquacult Int 21, 497-509.

41. Song C, Chang XJ, Bean KM, et al. (1999) Molecular characterization of cytosolic phospholipase A2-beta. J Biol Chem 274, 17063-17067.
42. Nalefski EA, Sultzman LA, Martin DM, et al. (1994) Delineation of two functionally distinct domains of cytosolic phospholipase $\mathrm{A} 2$, a regulatory $\mathrm{Ca}(2+)$-dependent lipid-binding domain and a $\mathrm{Ca}(2+)$-independent catalytic domain. J Biol Chem 269, 18239-18249.

43. Sæle Ø, Nordgreen A, Olsvik PA, et al. (2011) Characterisation and expression of secretory phospholipase A2 group IB during ontogeny of Atlantic cod (Gadus morhua). BrJ Nutr 105, 228-237.

44. Cahu CL, Zambonino Infante JL \& Barbosa V (2003) Effect of dietary phospholipid level and phospholipid:neutral lipid value on the development of sea bass (Dicentrarchus labrax) larvae fed a compound diet. BrJ Nutr 90, 21-28.

45. Buchet V, Zambonino Infante JL \& Cahu CL (2000) Effect of lipid level in a compound diet on the development of red drum (Sciaenops ocellatus) larvae. Aquaculture 184, 339-347. 